\title{
S100, bcl2 and myeloperoxid protein expirations during periodontal inflammation
}

\author{
Yevhen Kuzenko ${ }^{1 *}$, Anatoliy Romanyuk ${ }^{1}$, Antonina Politun² and Ludmila Karpenko ${ }^{1}$
}

\begin{abstract}
Background: Periodontal inflammation is characterized by injuries in collagen, epithelial, bone tissues. The hypotheses to be tested were relationship between the $\mathrm{s} 100, \mathrm{bcl} 2$ and myeloperoxidase in gingival tissues (MPO does affect the level of s100, bcl2). The object of this study was to investigate of s100 expression, bcl2 expression and myeloperoxidase expression in periodontal inflammation.
\end{abstract}

Methods: 27 patients (giant-cell epulis) and 30 patients (acute and chronic inflammations) were included in the study for s100 expression, bcl2 expression and myeloperoxidase expression by immunohistochemistry and hematoxylin - eosin.

Results: Giant-cells in epulis positivity for myeloperoxidase has been observed in $100 \%$ However, only $75.31 \%$ of giant-cells were positive for bcl2 expression. Acute $98.2 \%$, and chronic $89.28 \%$ inflammation was a significant positive for myeloperoxidase. The immunohistochemical findings of s100, bcl 2 and myeloperoxidase in epithelial layers have showed the result of $100 \%, 82,2 \%, 100 \%$ positive cells in acute and $100 \%, 78.25 \%, 100 \%$ in chronic process of inflammation respectively.

Conclusion: The results indicate that the pathogenesis of periodontal inflammation might involve inhibition of cell death, through the overexpression of bcl-2, due to identifying factors myeloperoxidase (result in the DNA damage by the product of catalysis). The highest levels of s100 activity have been found at sites with chronic inflammation.

\section{Background}

Bacterial infections are the most important etiologic agents involved in acute and chronic periodontitis, it is multifactorial disease that leads to the destruction of the bone periodontium [1]. Inflammatory cells infiltration has been resulted from periodontal plasma cells: neutrophil, T- \& B- lymphocytes and macrophages [2]. Periodontal lesions have been characterized by a persistence of infiltrating inflammatory cells, which may be responsible for the bone collagens resorcinol. Research by Baelum V. \& Lopez R. [3] demonstrated that periodontal disease affects between $10 \%$ and $15 \%$ of the world's population, being the greatest cause of tooth loss.

Inflammatory cells (plasma cells) have expressed in myeloperoxidase. Polymorphonuclear neutrophils are largely expressed the myeloperoxidase in plasma cells [4]. The myeloperoxidase gene is located on chromosome 17 (17q23.1) [5].

\footnotetext{
* Correspondence: kuzenko_yevhen@rambler.ru

'Department of Pathological Anatomy, Sumy State University, Sumy, Ukraine Full list of author information is available at the end of the article
}

Myeloperoxidase (MPO) have catalyzed the synthesis of microbicidal hypochlorous acid enabling the defence against bacteria [6]. Furthermore, plasma cells synthesize hypochlorous acid from $\mathrm{H}_{2} \mathrm{O}_{2}$ and $\mathrm{NaCl}$. Hydroxyl radical $(-\mathrm{OH})$ is mostly active in damaging important molecules such as DNA proteins and lipids [7]. Hydrogen peroxide $\left(\mathrm{H}_{2} \mathrm{O}_{2}\right)$ being a potent agent of oxygen species, is capable of crossing the nuclear membrane and damaging the DNA. [8] There is growing support for the claim that inflammation induces DNA damage which leads to apoptosis in periodontal cells [9] Furthermore, the apoptotic stimuli can trigger apoptosis via different mechanisms, including specific cell death receptors and ligands, such as cd95 [10], stress signals, inducing molecules directly or indirectly in apoptosis, via p53. Bcl2 is a member of anti-apoptotic family proteins that can prevent or reduce cell death induced by a variety of stimuli [11]. The BCL-2 gene was identified in the chromosome human $t(14 ; 18)$ [12]. The intrinsic death pathway is initiated by the mitochondrial

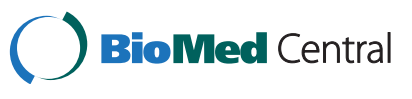

(c) 2015 Kuzenko et al. Open Access This article is distributed under the terms of the Creative Commons Attribution 4.0 International License (http://creativecommons.org/licenses/by/4.0/), which permits unrestricted use, distribution, and reproduction in any medium, provided you give appropriate credit to the original author(s) and the source, provide a link to the Creative Commons license, and indicate if changes were made. The Creative Commons Public Domain Dedication waiver (http://creativecommons.org/publicdomain/zero/1.0/) applies to the data made available in this article, unless otherwise stated. 
release of cytochrome $c$, a process that is inhibited by anti-apoptotic bcl2 proteins [13].

S100 proteins have expressed in the neutrophils cytosol, monocytes, activated macrophages, and keratinocytes and released during activation or death of these cells. The S100 gene family includes at least 13 members that locate as a cluster on chromosome 1q21 [14]. s100 proteins also known as L1 antigens, calgranulin A and B, macrophage migration inhibitory, factor-related protein (MRP) and cystic fibrosis antigen, have several functions in inflammatory reactions [15].

The results by Sun-Hee Heo et. al. [16] have shown the expression patterns of S100A2 in gingival tissues during bacterial lipopolysaccharide stimulation. S100A2 expression was upregulated by bacterial lipopolysaccharide.

We have hypothesis states that there is the relationship between the s100, bcl2 and myeloperoxidase in gingival tissues (MPO does affect the level of s100, bcl2).

The aim of this study is to compare the expression levels of s100, bcl2 and MPO in gingival tissues on different stages of periodontal disease and compared to the giant-cell epulis.

\section{Methods}

\section{Patient selection and of gingival tissues collection}

The study samples have included the periodontal and epulis tissues of the patients. The subjects were divided into two equal groups:

Patient Group (Group 1). Giant cell granuloma specimens were collected from 27 people who had a morphologically diagnosis of giant cell granuloma (eight males and 14 females, age range 30 to 70 years, mean age, 47,51 \pm 12.37 years).

Control group (Group 2) consisted of 30 patients who had died in Sumy Regional Hospital. The patients had various somatic diagnoses (not atherosclerotic complications) and dental - parodontit. 17 males and 13 females, age range 43 to 69 years, mean age, $57.33 \pm 8.31$ years have been investigating. The specimens of overgrown gingiva were collected during jaws sawing procedures. After group 2 tissue samples stained by hematoxylin eosin foo, all samples were divided in two groups (acute and chronic). Control group has two subgroups. Acute subgroups - 13 ( 5 males and 3 females, age range 43 to 69 years, mean age, $54.38 \pm 7.9$ years). Chronic subgroups - 17 (7 males and 15 females, age range 44 to 68 years, mean age, $59.58 \pm 8.11$ years).

Informed written consent was obtained from all study subjects in accordance with guidelines established by the Ukraine Health Council. The present study was approved by the Sumy State University (Protocol no. 5/ 2012).

\section{Hematoxylin and eosin (H\&E)}

Stains have been used for at least a century and are still essential for identifying various tissue types and the morphologic change.

\section{Immunostainings}

For s100, bcl2 and MPO have been performed formalinfixed $(\mathrm{pH} \mathrm{7,4)}$ tissue. Paraffin-embedded tissue sections have been treated dy mouse monoclonal anti-s100, antibcl2 and anti-myeloperoxidase (Thermo Fisher Scientific $\mathrm{UK})$. Briefly, $4 \mu \mathrm{m}$ thick tissue sections were dewaxed in xylene and were placed in to water through graded alcohols. Antigen retrieval has been performed by microwaving slides in $10 \mathrm{mM}$ citrate buffer ( $\mathrm{pH}$ 6.2) for $30 \mathrm{~min}$ at high power, according to the manufacturer's instructions. To remove the endogenous peroxidase activity, the sections have been treated with freshly prepared $1.0 \%$ hydrogen peroxide in the dark for $30 \mathrm{~min}$ at $37{ }^{\circ} \mathrm{C}$ temperature. Non-specific antibody binding was blocked by means of blocking serum. The sections were incubated for $30 \mathrm{~min}$, at $37^{\circ} \mathrm{C}$ temperature, with the primary antibodies against s100, bcl2 and myeloperoxidase diluted 1:100 in phosphate buffered saline (PBS) pH 7.2 then a triple washing with PBS follows. Anti-(mouse IgG)-horseradish peroxidase conjugate (1:40 000 dilution) has been fulfilled for the detection of the $\mathrm{S100}, \mathrm{Bcl} 2$ and MPO primariy antibodies, then the sections were incubated for $20 \mathrm{~min}$, at $37^{\circ} \mathrm{C}$ temperature. The colour was visualized by DAB.

The appearance of the positive factors was detected semiquantitatively by counting of positive giant cells in visual field.

The data were analysed using STATISTICA 8.0 software, user version STA862D175437Q. The results have been presented as mean \pm SD. The normalize test have been use before analysis of the data. Also, the nonparametric Student method was applied to perform a simple comparative analysis. The value of $\mathrm{P}<0.05$ have been considered to be a significant.

\section{Results}

The groups 1 and 2 of men and women consisted mostly age range 30 - to 70 -years. Group 1 giant cells occurred in the lower jaw (55\%) more frequently than in the upper jaw. In the group 2 the patients have been divided into 13 with acute and 17 with chronic inflammations.

In Fig. 1a A we observed low-size cell infiltration in acute inflammation. Significant cell infiltration and proliferating epithelium (Fig. 1b) appeared to be more intensive in the chronic inflammation. Acute and chronic inflammatory cells are circulating leukocytes, plasma cells and tissue macrophages.

Peripheral giant cell epulis is shown in Fig. 1c Microscopic examination has revealed the tissue with the 
abundance of giant-cells (Fig. 1c F), fibrous connective tissue, areas of haemorrhages (Fig. 1c E) and few capillaries. There was no sign of malignancy. Chronic inflammation when the macrophages fail to disintegrated various particles, fuse together and form multinucleated giant cells. Besides, morphologically distinct giant cells also appear in some tumours also.

$\mathrm{S} 100, \mathrm{Bcl} 2$ and MPO expressed in giant-cells. S100 expression, bcl2 expression and myeloperoxidase expression in giant-cells epulis are shown in Fig. 2. By immunohistochemistry, $100 \%$ of giant-cells appeared to be positive for myeloperoxidase, whereas only $75,31 \%$ of giant-cells were positive for $\mathrm{Bcl} 2(\mathrm{P}<0.05)$. By the fact $\mathrm{s} 100$ protein has expressed in $10,72 \%$ of giant-cells. Myeloperoxidase has physiologically expressed in plasmatic cells of epulis 87,69 \%. s100 and bcl 2 have expressed in plasmatic cells $24,34 \%(\mathrm{P}<0.05)$ and $11,28 \%$ respectively, bcl 2 and myeloperoxidase expression being weak or absent in the connective tissue.

The immunoexpression of s100, bcl2 end MPO (Group 2) have been confirmed by the presence of brown stained cytoplasm in cell infiltration. In general, s100 staining was more intensive in the plasmatic cells. In acute inflamation S100 (Fig. 2) only $36,2 \pm 5,3 \%$ of the cells appeared to be positive. The cell infiltration, showed bcl 2 immunoreactivity figured $76,1 \pm 3,3 \%(\mathrm{P}<0.05)$ in acute process (Fig. 2$)$. Myeloperoxidase has expressed in 98,2 $\pm 5,9 \%(\mathrm{P}<0.01)$ positive cells in acute inflammation.

Figure 2 shows the results of the s100, bcl2 and MPO expression in chronic process.
Myeloperoxidase $82,28 \pm 2,5 \% \mathrm{P}<0.01$ was expressed in chronic plasmatic cell infiltration during inflammation. Bcl 2 was expressed in chronic plasmatic cells infiltration $55,67 \pm 6,1 \% \mathrm{P}<0.05$. The immunoexpression of S100 in cell infiltration has shown the result of $95,0 \pm 0.31 \%$ positive cells.

The immunoexpression of s100, bcl2 and MPO in epithelial layers (acute process) have shown the result of $100 \%, 82,2 \pm 2.93 \%$ and $100 \%$ respectively. In chronic process of inflammation the positive cells have demonstratrd s100 - $100 \%$, bcl $2-78,25 \pm 4,23 \%$ and myeloperoxidase - $100 \%$ respectively.

\section{Discussion}

This study has claimed that MPO was able to stimulate higher of bcl2 expression in inflammation cells during chronic and acute process. Myeloperoxidase activity expressed in neutrophils recruited to the gingiva after chemical or immunological insults contributes to tissue destruction. Meloperoxidase might influence the extent and/or the severity of periodontal diseases [17].

High level of the MPO have been observed in giant cells. Elevated bcl2 expression levels can prevent cellular apoptosis, thereby inducing inflammatory cells to remain locally in the periodontal tissue, causing consequent excessive cytokine secretion which leads to the progressive destruction of periodontal tissues [1]. Myeloperoxidase can be liberated from activated neutrophils by degranulation only in moderate levels [18], and bcl2 availability protects regions. Cytolysis of neutrophils in the course

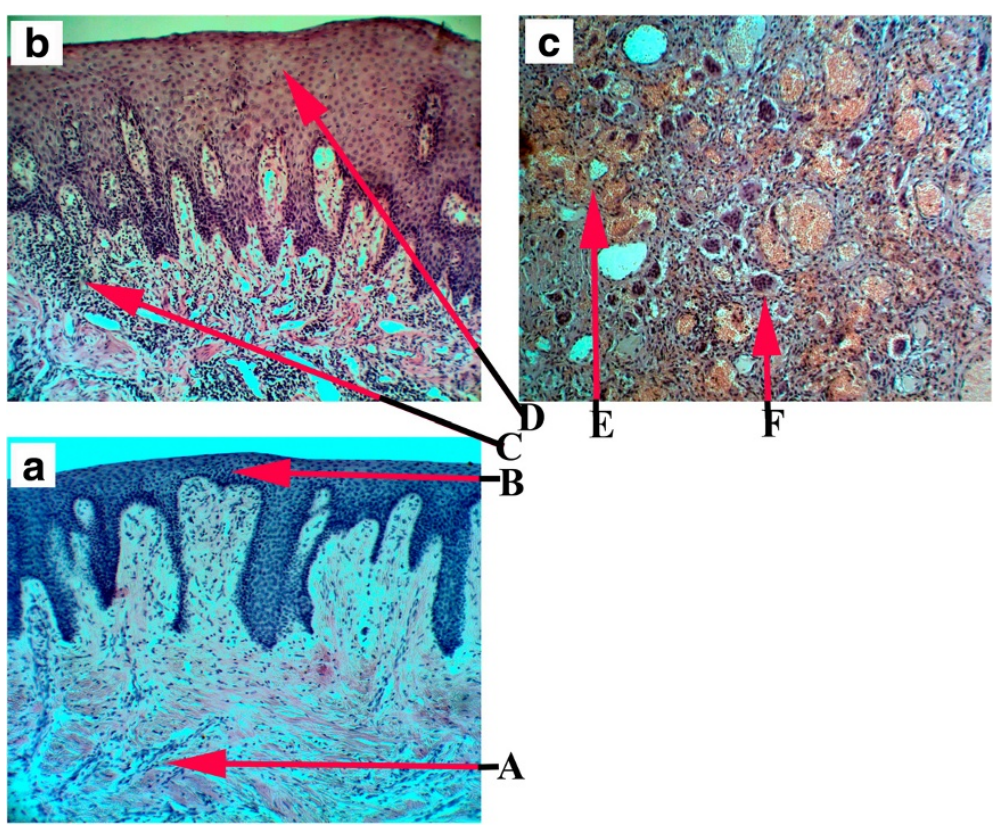

Fig 1 The periodontal tissues Haematoxylin and Eosin stained (x100 magnification) A (a) - pint-size cells infiltration with superimposed edema, B (a) - layers of the epithelium, C (b) - great cells infiltration with superimposed edema, D (a) - epithelial proliferation, E (c) - hemorrhage zone, F (c) - Giant cells 

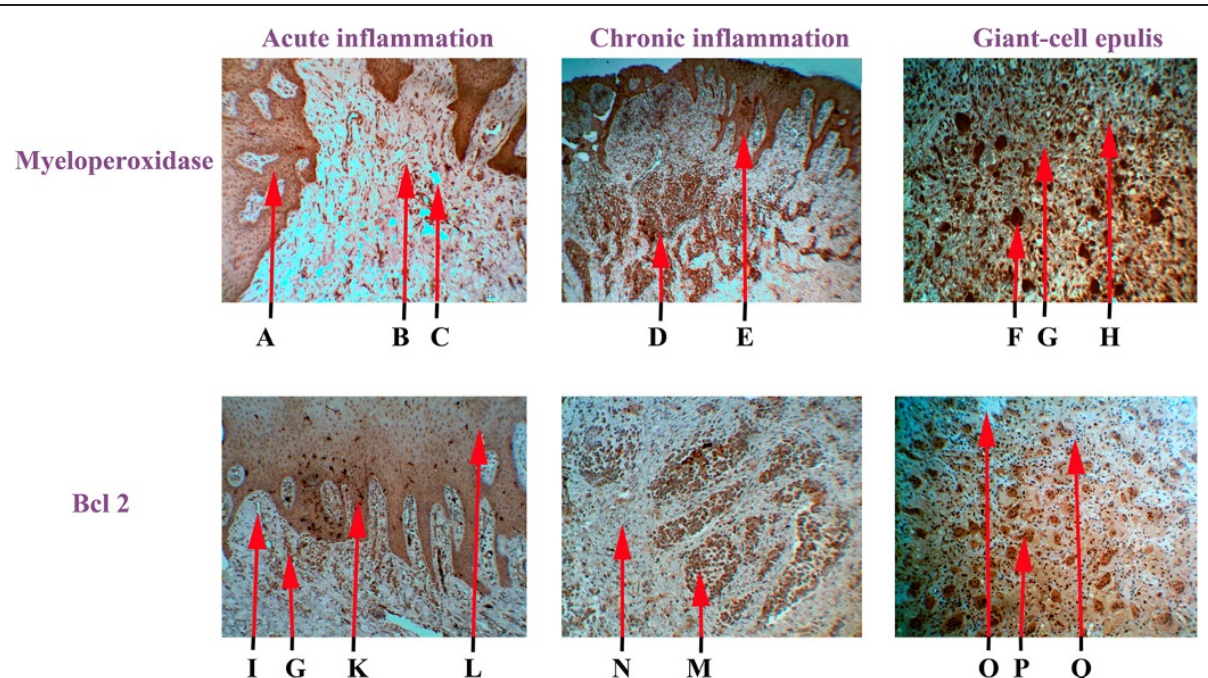

Bel 2
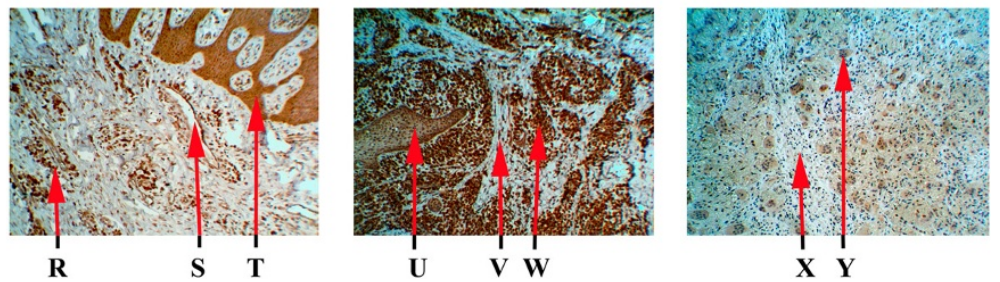

Fig 2 Expression of s100, bcl2and myeloperoxidase in gingival tissue (x100 magnification): A - Layers of the epithelium with myeloperoxidase expression, B - Blood cells infiltration with myeloperoxidase expression, C - Pericellular and perivascular edema, D - Blood cells infiltration with myeloperoxidase expression, E - Layers of the epithelium with myeloperoxidase expression and proliferation, F - Giant cells with

myeloperoxidase expression, $\mathrm{G}$ - Fibroblastic stroma, $\mathrm{H}$ - Blood cells infiltration with myeloperoxidase expression, I - Pericellular and perivascular edema, G - Blood cells infiltration with Bcl 2expression, K - Layers of the epithelium with high level of bcl 2 expression, L - Layers of the epithelium with bcl 2expression, $\mathrm{N}$ - Fibroblastic stroma, M - Blood cells infiltration with bcl 2 expression, $\mathrm{O}$ - Pericellular and perivascular edema, P - Giant cells with bcl 2 expression, Q - Blood cells infiltration with low bcl 2expression, R - Blood cells infiltration with s100 expression, $\mathrm{S}$ - Pericellular and perivascular edema, $\mathrm{T}$ - Layers of the epithelium with $\mathrm{S100}$ expression, $\mathrm{U}$ - Layers of the epithelium with low s100 expression, V - Fibroblastic stroma, W - Blood cells infiltration with s100 expression, X - Fibroblastic stroma, Y - Giant cells with "poor" s100 expression

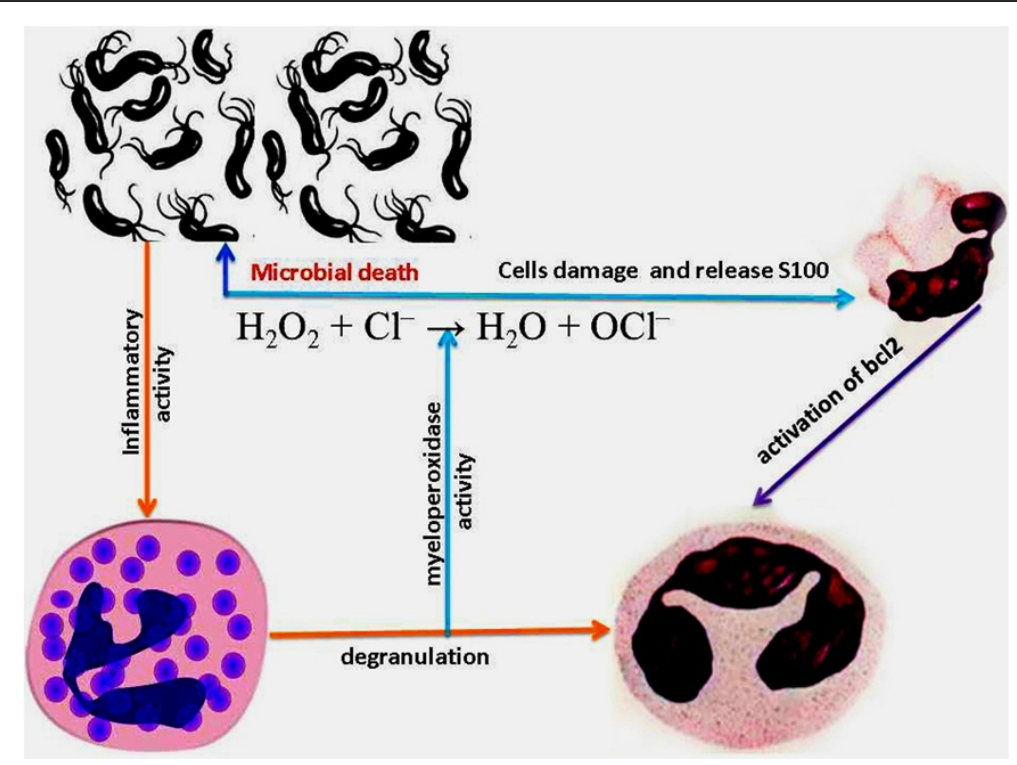

Fig 3 S100, bcl2 and myeloperoxid protein interaction during periodontal inflammation 
of inflammation formation could provide a release mechanism $[18,19]$ and explain the high levels of myeloperoxidase and S100. Activity of S100A12 and C-reactive protein can be markers of inflammatory activity in chronic periodontitis [20]. Previous studies have suggested that apoptosis is involved in the pathogenesis of inflammatory periodontal disease [21]. It has also been demonstrated that the higher frequency of $\mathrm{Bcl}-2$ expression results in progressive periodontal destruction [22].

Gamonall et all. [23] has not found statistical difference in varions amount of bcl2 in healthy gingiva and in gingiva of patients with periodontal disease. Our studies have confirmed the view of Pandilova [24] and Ellis et all. [25] that chronic progression of inflammation decrease expresses bcl-2. In human gingival fibroblasts with inflammation activation of bcl 2 has not been observed in different stages of the infection and giant-cell epulis. Sule Bulut et all. [26] results indicate that the pathogenesis of cyclosporin A induced gingival overgrowth might involve inhibition of apoptosis and overexpression of bcl-2 in the setting of high serum cyclosporin A. Our study has demonstrated a high level of bcl2 expression and inhibition of apoptosis in cells of gingival epithelium. We believe this is due to the epithelium protective functions. In gingival epithelium s100 is also related to the differentiation stage [27]. These positive cells are known to activate macrophages or neutrophils [28]. Research by Saito et al. [29] demonstrated numerous bcl-2-positive epithelial cells in gingival biopsies from patients who were taking nifedipine and phenytoin, indicating that this protein might be involved in the development of nifedipine-induced gingival hyperplasia. We believe that the presence of $\mathrm{Bcl}-2$ protein is not an indicator of giant cell epulis favorable courses.

S100 plays a important part in the immune response related to periodontitis. s100 binds $2 \mathrm{Ca} 2+$ and $2 \mathrm{Zn} 2+$ ions. If $\mathrm{Zn} 2+$ binds to $\mathrm{S} 100$ it decreases its $\mathrm{Ca} 2+$ affinity. S100 also interacts with p53 in a $\mathrm{Ca} 2+-$ dependent manner, which affects stability of S100-p53 interaction [30] Aforesaid s100-p53 interaction leads to inhibition of apoptosis during inflammation. The $\mathrm{Bcl}-2$ protein is a potent inhibitor of cell death, whereas the wild-type p53 protein activates the apoptotic pathway [5].

Mutated p53 loses this function and allows the proliferation of neoplastic cells. Bcl-2 also modulates the function of p53 and triggers cell proliferation and transformation [31].

Thr expression of S100 have been detected as proinflammatory phagocytes cells at sites of intestinal inflammation [32, 33]. Systemic autoimmune diseases (dermatomyositis, systemic lupus erythematosus, Kawasaki disease etc.) have clear association with S100 expression in macrophages infiltraton with degeneration of tissue [34, 35].

\section{Conclusion}

Investigations on bcl2 marker in gingival cells during periodontal inflammation we suggestion that periodontium tissues, continuously exposed to bacterial infections may contain cells with high level of myeloperoxidase results that damage DNA by product of catalysis.

The highest levels of s100 activity have been found at sites with chronic inflammation. Our results suggest that low s100 expression may play an important role in the activity of giant cells in giant cell epulis. That is considered to be the most significant factors of prognosis in giant cell granuloma. As a result of our research we created a diagram Fig. 3.

\section{Competing interests}

The authors declare that they have no competing interests.

\section{Authors' contributions}

PCCF were responsible for the study design. SCT analyzed and interpreted the data. MTX wrote the report. BFPP did the laboratory work. RM, helped to draft the manuscript. All authors read, commented and approved the final article.

\section{Acknowledgments}

The authors would like to thank the Laboratory of Immunology at the Sumy State University.

\section{Author details}

'Department of Pathological Anatomy, Sumy State University, Sumy, Ukraine. ${ }^{2} \mathrm{Head}$ of the Department of Therapeutic Dentistry, Kiev University UANM, Kyiv, Ukraine.

Received: 22 June 2015 Accepted: 22 July 2015

Published online: 07 August 2015

\section{References}

1. Carvalho-Filho PC, Trindade SC, Olczak T, Sampaio GP, Oliveira-Neto MG, Santos HA, et al. Porphyromonas gingivalis HmuY stimulates expression of Bcl2 and Fas by human CD3+ T cells. BMC Microbiol. 2013;13:206.

2. McGhee ML, Ogawa T, Pitts AM, Moldoveanu Z, Mestecky J, McGhee JR, et al. Cellular analysis of functional mononuclear cells from chronically inflammed gingival tissue. Reg Immunol. 1989;2:103-7.

3. Baelum V, Lopez R. Periodontal epidemiology: towards social science or molecular biology? Community Dent Oral Epidemiol. 2004;32(4):239-49.

4. Cao CF, Smith QT. Crevicular fluid myeloperoxidase at healthy, gingivitis and periodontitis sites. J Clin Periodontol. 1989;16:17-20.

5. Levine AJ. p53, the cellular gatekeeper for growth and division. Cell. 1997:88:323-31.

6. Miyasaki KT, Nemirovskiy E. Myeloperoxidase isoform activities released by human neutrophils in response to dental and periodontal bacteria. Oral Microbiol Immunol. 1997;12:27-32.

7. Klebanoff SJ. Myeloperoxidase: friend and foe. J Leukoc Biol. 2005;77(5):598-625.

8. Takane M, Sugano N, Iwasaki H, Iwano Y, Shimizu N, Ito K. New biomarker evidence of oxidative DNA damage in whole saliva from clinically healthy and periodontally diseased individuals. J Periodontol. 2002;73(5):551-4.

9. Gamonal J, Bascones A, Acevedo A, Blanco E, Silva A. Apoptosis in chronic adult periodontitis anaiyzed by in situ DNA breaks, electron microscopy, and immunohistochemistry. Pariodontol. 2001;72:517-25.

10. Peter ME, Budd RC, Desbarats J, Hedrick SM, Hueber AO, Newell MK, et al. The CD95 Receptor: Apoptosis Revisited. Cell. 2000;129(4):427-50.

11. Reed J. BCl2 and the regulation of programmed cell death. J Cell Biol. 1994;124:1-6.

12. Volz A, Korge BP, Compton JG, Ziegler A, Steinert PM, Mischke D. Physical mapping of a functional cluster of epidermal differentiation genes on chromosome 1q21. Genomics. 1994;18(1):92-9.

13. Lane D, Lu X, Hupp T, Hall P. The role of p53 protein in the apoptotic response. Philos Trans R Soc Lond Scr B. 1994;345:277-80. 
14. Vaux DL, Cory S, Adams JM. BCl-2 gene promotes haemopoietic cell survival and cooperates with c-myc to immortalize pre-B cells. Nature. 1988;335(6189):440-2.

15. Becerik S, Afacan B, Oztürk VÖ, Atmaca H, Emingil G. Gingival crevicular fluid calprotectin, osteocalcin and cross-linked N-terminal telopeptid levels in health and different periodontal diseases. Dis Markers. 2011;31:343-52.

16. Heo SH, Choi YJ, Lee JH, Lee JM, Cho JY. S100A2 level changes are related to human periodontitis. Mol Cells. 2011:32:445-50.

17. Meisel P, Krause T, Cascorbi I, Schroeder W, Herrmann F, John U. Gender and smoking-related risk reduction of periodontal disease with variant myeloperoxidase alleles. Genes Immun. 2002;3:102-6.

18. Urban CF, Ermert D, Schmid M, Abu-Abed U, Goosmann C, Nacken W, et al. Neutrophil extracellular traps contain calprotectin, a cytosolic protein complex involved in host defense against Candida albicans. PLoS Pathog. 2009:5(10), e1000639.

19. Fuchs TA, Abed U, Goosmann C, Hurwitz R, Schulze I, Wahn V, et al. Novel cell death program leads to neutrophil extracellular traps. J Cell Biol. 2007;176(2):231-41.

20. Pradeep AR, Martande SS, Singh SP, Suke DK, Raju AP, Naik SB, et al. Correlation of human S100A12 (EN-RAGE) and high-sensitivity C-reactive protein as gingival crevicular fluid and serum markers of inflammation in chronic periodontitis and type 2 diabetes. Inflamm Res. 2014;63:317-23.

21. Bascones A, Gamonal J, Gomez M, Silva A, Gonzalez MA. New knowledge of the pathogenesis of periodontal disease. Quintessence Int. 2004;35:706-16.

22. Bulut S, Uslu H, Ozdemir HB, Bulut EO. Expression of caspase-3, p53 and $\mathrm{BCl}-2$ in generalized aggressive periodontitis. Head Face Med. 2006:2:17.

23. Gamonal J, Bascones A, Acevedo A, Blanco E, Silva A. Apoptosis in chronic adult periodontitis analyzed by in situ DNA breaks, electron microscopy, and immunohistochemistry. J Periodontol. 2001;72:517-25.

24. Pandilova M. Comparative analysis of apoptotic cell death during periodontal disease. Doctors Dissertation. 2003;78:258-356.

25. Ellis SD, Tucci MA, Serio FG, Johnson RB. Factors for progression of periodontal diseases. J Oral Pathol Med. 1998;27:101-5.

26. Bulut $\mathrm{S}$, Ozdemir BH, Alaaddinoĝlu EE, Oduncuoĝlu FB, Bulut OE, Demirhan B. Effect of Cyclosporin A on Apoptosis and Expression of p53 and bcl-2 Proteins in the Gingiva of Renal Transplant Patients. J Periodontol. 2005:76:691-5.

27. Hayashi N, Kido J, Kido R, Wada C, Kataoka M, Shinohara Y, et al. Regulation of calprotectin expression by interleukin-1alpha and tansforming growth factor-beta in human gingival keratinocytes. J Periodontal Res. 2007;42:1-7.

28. Echelard S, Hoyaux D, Hermans M, Daelemans P, Roth J, Philippart P, et al. S100A8 and S100A9 calcium-binding proteins: localization within normal and cyclosporin A-induced overgrowth gingiva. Connect Tissue Res. 2002;43:419-24.

29. Saito K, Mori S, Tanda N, Sakamoto S. Immunolocalization of c-Myc and bcl-2 proto-oncogene productrs in gingival hyperplasia induced by nifedipine and phenytoin. J Periodontol. 2000;71:44-9.

30. Mueller A, Schafer BW, Ferrari S, Weibel M, Makek M, Hochli M, et al. The calcium-binding protein S100A2 interacts with p53 and modulates its transcriptional activity. J Biol Chem. 2005;280:29186-93.

31. Ryan JJ, Prochownik E, Gottlieb CA. C-myc and bcl-2 modulate p53 function by altering p53 subcellular trafficking during the cell cycle. Proc Natl Acad SciUSA. 1994;91:5878-82

32. Rugtveit J, Nilsen EM, Bakka A, Carlsen H, Brandtzaeg P, Scott H. Cytokine profiles differ in newly recruited and resident subsets of mucosal macrophages from inflammatory bowel disease. Gastroenterology. 1997:112:1493-505.

33. Lugering N, Stoll R, Kucharzik T, Schmid KW, Rohlmann G, Burmeister G, et al. Immunohistochemical distribution and serum levels of the Ca(2)-binding proteins MRP8, MRP14 and their heterodimeric form MRP8/14 in Crohn's disease. Digestion. 1995;56:406-14.

34. Seeliger S, Vogl T, Engels I, Schröder JM, Sorg C, Sunderkötter C, et al. Expression of calcium-binding proteins MRP8 and MRP14 in inflammatory muscle diseases. Am J Pathology. 2003;163:947-56.

35. Foell D, Ichida F, Vogl T, Yu X, Chen R, Miyawaki T, et al. S100A12 (EN-RAGE) in monitoring Kawasaki disease. Lancet. 2003;361:1270-2.

\section{Submit your next manuscript to BioMed Central and take full advantage of:}

- Convenient online submission

- Thorough peer review

- No space constraints or color figure charges

- Immediate publication on acceptance

- Inclusion in PubMed, CAS, Scopus and Google Scholar

- Research which is freely available for redistribution

Submit your manuscript at www.biomedcentral.com/submit 